\title{
DESAIN PEMBELAJARAN MATERI HUBUNGAN ANTAR GARIS YANG MENDUKUNG PEMAHAMAN KONSEP SISWA
}

\author{
Rika Firma Yenni ${ }^{1}$, Malalina ${ }^{2}$ \\ Program Studi Pendidikan Matematika, FKIP, Universitas Tamansiswa, Palembang ${ }^{1,2}$ \\ e-mail: rika_firma@unitaspalembang.ac.id
}

\begin{abstract}
ABSTRAK
Peran guru tak lebih dari seorang fasilitator, moderator atau evaluator. sedangkan peran siswa lebih banyak aktif untuk berfikir dan mengkomunikasikan argumentasinya, menjustifikasi jawaban, serta melatih nuansa demokrasi dengan menghargai pendapat atau strategi teman lain. Penelitian ini bertujuan menghasilkan Local Instructional Theory (LIT) dalam pembelajaran materi hubungan antar garis yang mendukung pemahaman konsep siswa di kelas IV Sekolah Dasar. Pada materi ini, menuntut siswa dapat menyelesaikan permasalahan hubungan antar garis secara kontekstual. Subjek penelitian adalah siswa kelas IV MI Fajar Siddiq Palembang. Metode yang digunakan adalah design research terdiri dari tiga tahap, yaitu: preliminary design, design experiment (pilot experiment dan teaching experiment), dan retrospective analysis. Namun pada penelitian ini hanya dilakukan sampai pada tahap pilot experiment. Penelitian ini mengembangkan hasil pembelajaran hubungan antar garis dengan menunjukkan aktivitas dan prosedur serta strategi siswa dalam menemukan ide atau strategi dalam mendeskripsikan materi hubungan antar garis. Pada bagian ini, akan dibahas penggunaan garis lurus sebagai starting point pembelajaran hubungan antar garis dengan Pendidikan Matematika Realistik Indonesia (PMRI) sebagai pendekatan yang mendukung aktivitas dari penggunaan konteks tersebut. Selain itu, perubahan dari Hypothetical Learning Trajectory (HLT) ke Learning Trajectory (LT) melalui aktivitas, dilakukan dengan pengumpulan data menggunakan lembar observasi, wawancara, rekaman video, foto, dan lembar aktivitas siswa.
\end{abstract}

Kata kunci :

design research, garis lurus, hubungan antar garis, PMRI

\begin{abstract}
The purpose of this study was to see the role of using activities to describe straight lines in the material of the relationship between lines. In this material, requires students to solve the problem of the relationship between the lines contextually. The research subjects were fourth grade students of MI Fajar Siddiq Palembang. The method used was design research consisting of three stages, namely: preliminary design, experimental design (pilot experiment and teaching experiment), and retrospective analysis. However, this research was only carried out until the pilot experiment stage. This study develops the results of learning the relationship between lines by showing the activities and procedures and strategies of students in finding ideas or strategies in describing the material on the relationship between the lines. In this section, we will discuss the use of straight lines as the starting point for learning the relationship between lines with Indonesian Realistic Mathematics Education (PMRI) as an approach that supports the activities of using this context. In addition, the change from Hypothetical Learning Trajectory (HLT) to Learning Trajectory (LT) through activities was carried out by collecting data using observation sheets, interviews, video recordings, photos, and student activity sheets.
\end{abstract}

Keywords :

design research, straight lines, relationships between lines, PMRI

\section{PENDAHULUAN}

struktur yang fleksibel dengan

memperlakukan siswa sebagai individu yang

memiliki karakteristik khusus dan mandiri.

Menurut Jamaris (2013), pendidikan mempunyai peranan besar dalam mencapai keberhasilan dan perkembangan siswa. Pendidikan merupakan proses yang berkesinambungan dan senantiasa berinteraksi dengan lingkungan, berbentuk konteks yang digunakan dalam 


\section{$\pi$ (Phi)}

pembelajaran. Menurut Freudenthal pendidikan harus mengarahkan siswa kepada penggunaan berbagai situasi dan kesempatan untuk menemukan kembali dengan cara mereka sendiri (Hadi, 2017). Proses pembelajaran yang dimulai dari dalam diri siswa merupakan tahap menuju proses pembelajaran sehingga dapat terlaksana dengan baik, kemudian dikembangkan dan dikaitkan dengan konten yang ada.

Berdasarkan Permendiknas Nomor 23 tahun 2006, mata pelajaran matematika perlu diberikan kepada semua siswa sebagai dasar untuk membekali mereka kemampuan berpikir logis, analitis, sistematis, kritis, kreatif, dan bekerja sama. Pembelajaran matematika tidak hanya mencakup berbagai penguasaan konsep matematika tetapi juga terkait dengan aplikasinya dalam kehidupan nyata. Salah satu ruang lingkup mata pelajaran matematika Sekolah Dasar meliputi materi hubungan antar garis yang dapat diaplikasikan dalam berbagai aktivitas kehidupan sehari-hari. Hubungan antar garis dapat berupa berpotongan, sejajar, berimpit, dan bersilangan. Banyak benda-benda di sekitar kita yang terlihat seperti garis-garis sejajar atau garis-garis yang saling berpotongan, misalnya barisan pohon pada suatu perkebunan yang terlihat seperti garisgaris yang sejajar. Selain itu ada pula bendabenda yang tampak seperti garis-garis berpotongan, misalnya pertemuan dua lintasan kereta api dan perpotongan rangka sebuah bangunan. Hubungan antar garis juga berguna untuk menentukan besarnya gradien (kemiringan) suatu garis. Selain itu juga berguna dalam materi garis singgung kurva, garis singgung lingkaran serta garis singgung pada irisan kerucut. Untuk itu siswa perlu dibekali materi hubungan antar garis mulai dari Sekolah Dasar, agar lebih mudah memahaminya pada tingkat yang lebih lanjut.

Hubungan antar garis merupakan salah satu materi yang dipelajari sejak kelas IV Sekolah Dasar, dengan Kompetensi Dasar menjelaskan dan mengidentifikasi hubungan
Jurnal Pendidikan Matematika Volume 5 Nomor 1 Tahun 2021 antar garis (sejajar, berpotongan, berimpit) menggunakan model konkret. Berdasarkan hal tersebut maka siswa diharapkan dapat menyelesaikan setiap permasalahan yang berhubungan dengan materi hubungan antar garis, dimana materi ini sering masuk pada Ujian Nasional.

Salah satu usaha yang dapat dilakukan untuk meningkatkan kualitas pembelajaran khususnya pada materi hubungan antar garis adalah dengan menggunakan pendekatan Pendidikan Matematika Realistik Indonesia (PMRI). PMRI mengacu pada konsep Freudenthal dalam Realistic Mathematics Education (RME). Dua pandangan yang penting dari Freudenthal adalah (1) mathematics must be connected to reality; and (2) mathematics as human activity (Zulkardi, 2010). Ide utamanya adalah siswa harus diberi kesempatan untuk menemukan kembali (re-invention) ide dan konsep matematika melalui penjelajahan berbagai situasi dan persoalan dunia nyata (real world) dengan bimbingan orang dewasa dan secara bertahap berkembang menuju kepemahaman matematika.

Menurut penelitian Becker \& Selter (TIM MKPBM, 2001), siswa yang memperoleh pendekatan RME mempunyai skor yang lebih tinggi dibandingkan dengan siswa yang memperoleh pembelajaran dengan pendekatan tradisional dalam hal keterampilan berhitung, lebih khusus lagi dalam aplikasi. Sejalan dengan hal tersebut, dari beberapa penelitian yang dilakukan di Indonesia diperoleh kesimpulan yang relatif sama dan dapat dijadikan tolak ukur dalam memilih pendekatan pembelajaran yakni dengan menggunakan pendekatan PMRI dapat memperbaiki hasil belajar, sikap, dan minat siswa. Meskipun pembelajaran PMRI diadaptasi dari pembelajaran RME, namun PMRI dikembangkan menyesuaikan dengan konteks budaya lokal dan kondisi yang terjadi di Indonesia (Sembiring, 2010).

PMRI merupakan teori pembelajaran yang bertitik tolak dari hal-hal yang 'real' atau pernah dialami siswa, menekankan 
keterampilan proses 'doing mathematics', berdiskusi dan berkolaborasi, beragumentasi dengan teman sekelas sehingga mereka dapat menemukan sendiri ('student inventing') sebagai kebalikan dari ('teacher telling') dan pada akhirnya menggunakan matematika itu untuk menyelesaikan masalah baik secara individu maupun kelompok (Zulkardi dan Ilma, 2010). Peran guru tak lebih dari seorang fasilitator, moderator atau evaluator. sedangkan peran siswa lebih banyak aktif untuk berfikir dan mengkomunikasikan argumentasinya, menjustifikasi jawaban, serta melatih nuansa demokrasi dengan menghargai pendapat atau strategi teman lain.

Matematika merupakan suatu bentuk aktivitas manusia (mathematics is a human activity) menunjukkan bahwa Freudenthal tidak menempatkan matematika sebagai suatu produk jadi, melainkan sebagai suatu bentuk aktivitas atau proses (Wijaya, 2012). Dalam falsafah pendekatan realistik, pembelajaran matematika dipandang sebagai suatu bentuk kegiatan untuk mengkonstruksi konsep matematika bukan sebagai produk yang siap pakai (barang jadi). Freudenthal menekankan guided reinvention sebagai proses yang dilakukan siswa secara aktif untuk menemukan kembali suatu konsep matematika dengan bimbingan guru. Jadi, dalam hai ini pembelajaran berpusat pada siswa (student center learning) dan guru hanya sebagai fasilitator.

Jadi penelitian ini bertujuan menghasilkan Local Instructional Theory (LIT) dalam pembelajaran materi hubungan antar garis yang mendukung pemahaman konsep siswa di kelas IV Sekolah Dasar. Berdasarkan hal tersebut maka peneliti akan mendesain materi hubungan antar garis dengan pendekatan PMRI untuk mendukung pemahaman konsep siswa.

\section{METODE PENELITIAN}

Metode penelitian ini menggunakan Design Research dengan tiga tahapan yaitu preparing for the experiment and preliminary design, the design experiment (pilot experiment dan teaching experiment) serta the retrospective analysis (Gravemeijer dan Cobb, 2006). Metode ini sebagai alat untuk menjawab permasalahan sehingga tercapai tujuan penelitian. Subjek penelitian untuk tahap pilot experiment sebanyak 6 orang siswa yang terbagi menjadi 3 kemampuan yaitu tinggi, sedang, dan rendah. Tahap teaching experiment sebanyak 25 orang siswa, yang rencananya akan dilanjutkan nanti setelah situasi kondusif dan aman dari Covid-19. Penelitian dilakukan di kelas IV MI Fajar Siddiq Palembang. Prinsip dari penelitian ini adalah bagaimana dan mengapa guru mendesain pembelajaran yang berguna untuk menyelidiki dan menjelaskan alur berpikir siswa pada materi hubungan antar garis.

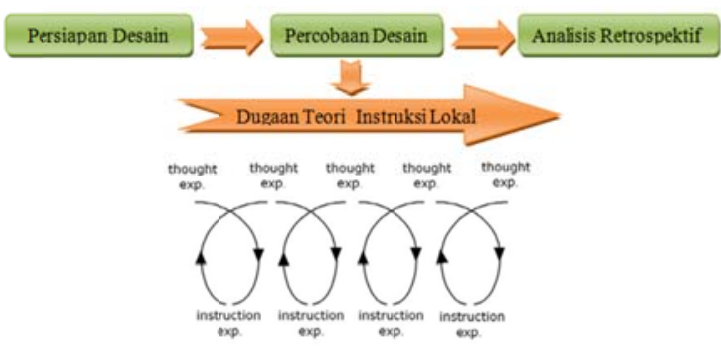

Gambar 1. Siklik Design Research (Gravemeijer, 2004)

\section{Prosedur Penelitian}

Tahap 1 : Persiapan Percobaan dan Desain Pendahuluan (Preparing for The Experiment and Preliminary Design)

Dimulai dengan mempelajari berbagai kajian literatur sebelum merancang aktivitas pembelajaran selama penelitian. Gravemeijer \& Cobb (2006) menjelaskan tujuan utama tahap ini adalah memformulasikan Local Instructional Theory (LIT) yang dielaborasi dan diperbaiki selama pelaksanaan eksperimen. Sederetan aktivitas yang memuat konjektur berpikir siswa dikembangkan oleh peneliti melalui Hypothetical Learning Trajectory (HLT) yang bersifat dinamis dan dapat 
disesuaikan dengan strategi berpikir siswa yang terjadi pada saat design experiment. Kegiatan persiapan sebelum melakukan percobaan adalah Kajian dan Mendesain Dugaan Lintasan Pembelajaran atau HLT.

Tahap II: Percobaan Desain (The Design Experiment)

Kegiatan yang dilakukan adalah mengimplementasikan desain pembelajaran dengan tujuan mengeksplorasi, mengetahui strategi dan pemikiran siswa dalam mempelajari materi hubungan antar garis. Ada dua siklus yaitu pilot experiment dan teaching experiment. Namun pada penelitian ini dilakukan sampai pilot experiment dikarenakan Covid-19.

Pilot experiment dilaksanakan untuk mengetahui pengetahuan awal siswa dan untuk mengujicobakan rancangan HLT yang sudah dibuat, melibatkan minimal 6 orang siswa dari kelas non subjek penelitian. Agar HLT tepat sasaran dan mencapai tujuan pembelajaran, peneliti berdiskusi dengan guru model dimana guru tersebut mengetahui siswa yang menjadi sampel. Selain itu, siswa diwawancarai pada proses pembelajaran guna mengetahui pemahaman, kemajuan, dan kesulitan siswa. Hasil diskusi dan saran dari guru serta hasil wawancara dengan siswa, digunakan sebagai bahan pertimbangan untuk memperbaiki HLT tersebut.

\section{Tahap III: Analisis Retrospektif (The Retrospective Analysis)}

Pada tahap ini peneliti melakukan refleksi terhadap pembelajaran yang telah dilakukan. Setelah ujicoba, data yang diperoleh dari aktivitas pembelajaran dianalisis dan hasilnya digunakan untuk merencanakan kegiatan ataupun untuk mengembangkan desain pada kegiatan berikutnya. Tujuannya adalah untuk mengembangkan LIT. Pada tahap ini, HLT digunakan sebagai panduan dan referensi utama dalam menjawab pertanyaan penelitian dan sebagai acuan untuk melakukan analisis. HLT dibandingkan dengan strategi dan proses berpikir siswa yang terjadi saat pembelajaran. Hal yang dianalisis tidak hanya yang mendukung HLT, melainkan juga contoh yang kontradiksi dengan konjektur yang didesain. Hasil dari tahap ini digunakan untuk menjawab pertanyaan penelitian, membuat kesimpulan, maupun memberikan rekomendasi bagaimana HLT dikembangkan untuk penelitian selanjutnya.

\section{HASIL DAN PEMBAHASAN}

Proses pembelajaran yang berlangsung terdiri dari beberapa aktivitas. Sebelum dan sesudah aktivitas dilakukan tes awal dan tes akhir guna mengetahui kemampuan pemahaman konsep siswa. Adapun aktivitas yang dilakukan adalah sebagai berikut:

\section{Aktivitas 1 : Mendeskripsikan Garis}

Tujuan Pembelajaran :

Siswa mampu mendeskripsikan garis lurus, sinar garis, dan segmen garis dengan menggunakan bahasa sendiri

Aktivitas:

Guru memulai pertemuan dengan mengeksplorasi pengetahuan awal siswa dengan melihat gambar benda-benda berbentuk garis. Kemudian mengingatkan kembali pengertian garis. Pada pertemuan ini, kegiatan yang dilakukan siswa yaitu siswa mendeskripsikan garis lurus, sinar garis, dan segmen garis, kemudian siswa mempresentasikan hasil diskusi mereka. Setelah semua kelompok mendiskusikan jawaban dari permasalahan pada Lembar Aktivitas 1, guru menggiring siswa untuk menjawab permasalahan selanjutnya yaitu, "Apa itu garis"? Adapun jawaban siswa untuk permasalahan tersebut seperti gambar 2 berikut: 
$\pi$ (Phi)

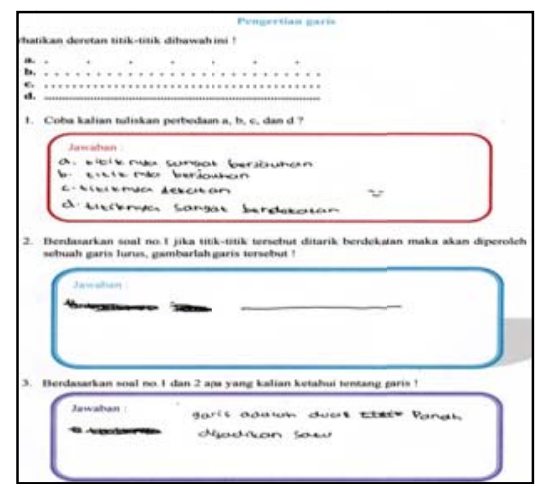

Gambar 2. Jawaban Siswa tentang Garis

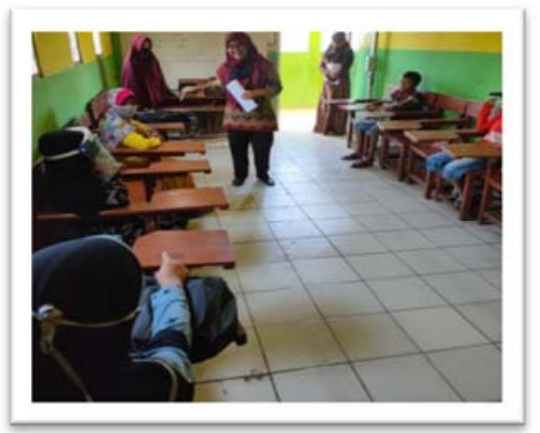

Gambar 3. Kegiatan Siswa pada Aktivitas 1

Pada akhir pembelajaran, guru mengajak siswa menyimpulkan hasil aktivitas pertama dan guru menginformasikan tentang kegiatan untuk aktivitas selanjutnya.

\section{Aktivitas 2 : Menentukan Hubungan Dua} Garis

Tujuan Pembelajaran :

Siswa mampu menentukan hubungan dua garis (sejajar, berpotongan, berimpit) Aktivitas :

Kegiatan pada aktivitas kedua ini yaitu menentukan hubungan antar dua garis. Pertama-tama siswa diminta untuk menuliskan pengertian garis sejajar, garis berpotongan, dan garis berhimpit. Kemudian siswa menggambar dua garis yang merupakan garis sejajar, garis berpotongan, dan garis berhimpit. Sehingga siswa dapat mengungkapkan dengan kata-katanya sendiri defenisi dari garis sejajar, garis berpotongan, dan garis berhimpit. Hasil jawaban siswa terlihat pada gambar 4 berikut:

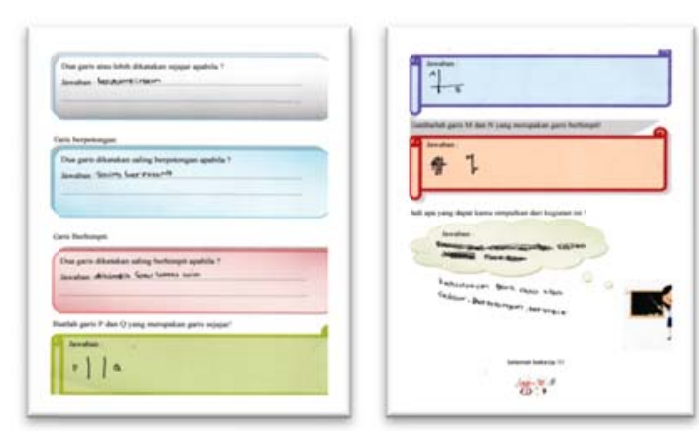

Gambar 4. Jawaban Siswa tentang Hubungan Dua Garis

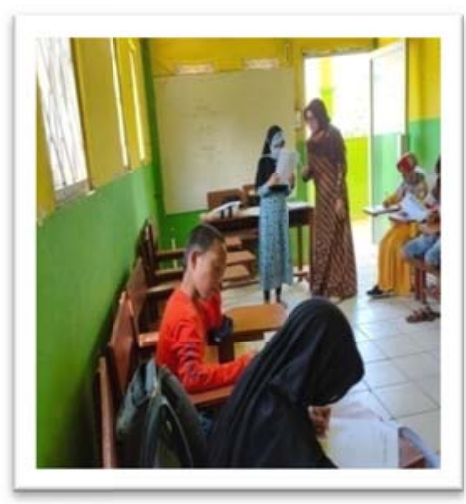

Gambar 5. Siswa Mempresentasikan Hasil Diskusinya

Pada soal yang diberikan semua siswa dapat menyelesaikannya dengan benar. Diakhir pembelajaran guru bersama-sama siswa menyimpulkan kegiatan pembelajaran

\section{Aktivitas 3 : Mengetahui Sudut}

Tujuan Pembelajaran :

Siswa mampu mengetahui sudut yang terbentuk jika dua garis sejajar dipotong oleh sebuah garis

Aktivitas :

Setelah menyelesaikan aktivitas 1 dan aktivitas 2, guru melanjutkan ke aktivitas 3 yaitu menetukan sudut yang terjadi jika dua garis sejajar dipotong oleh satu garis. Sebelum memulai kegiatan pembelajaran, guru menanyakan kembali apa itu pengertian garis dan kedudukan dua garis. Siswa sudah memahami pengertian dari garis dan kedudukan dua garis. Kemudian guru menuntun siswa menjawab soal yang terdapat pada LAS 3. Aktivitas 3 
$\pi$ (Phi)

ini terdiri dari permasalahan menentukan sudut jika dua garis sejajar dipotong oleh sebuah garis. Hasil jawaban siswa terlihat pada gambar 6 berikut:

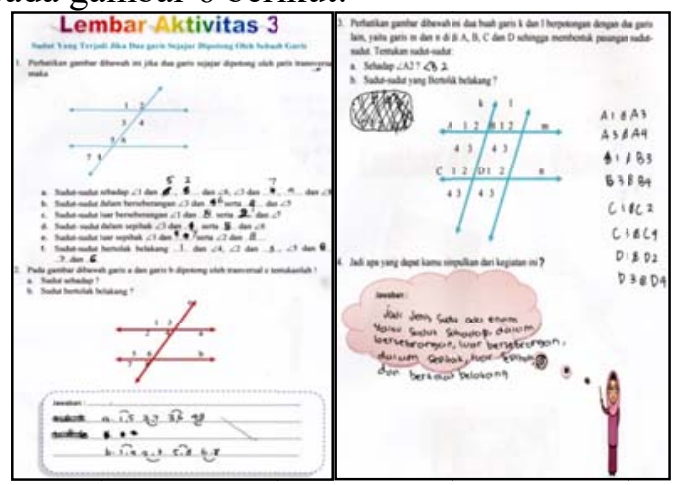

Gambar 6. Hasil Jawaban Siswa

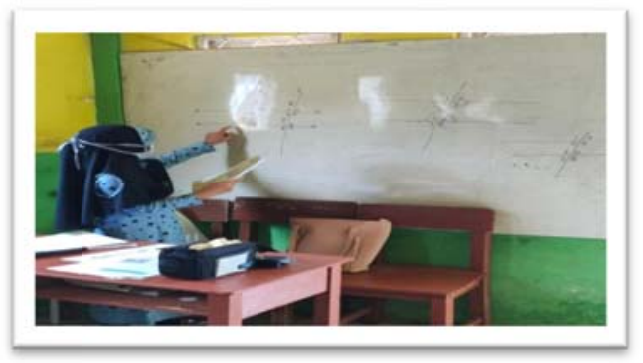

Gambar 7. Siswa Mempresentasikan Hasil Diskusinya

Kemudian salah satu kelompok tampil di depan kelas untuk mempresentasikan hasil diskusi mereka. Kelompok yang tampil menjelaskan hasil diskusi mereka tentang sudut yang terjadi jika dua garis sejajar dipotong oleh sebuah garis.

\section{Aktivitas 4 : Menerapkan Hubungan antar Garis}

Tujuan Pembelajaran :

Siswa mampu menerapkan hubungan antar garis dalam kehidupan sehari-hari Aktivitas :

Guru menginformasikan tujuan pembelajaran yaitu menerapkan prinsip hubungan antar garis dalam kehidupan sehari-hari. Guru membagi lembar aktivitas kepada siswa. Pada aktivitas keempat ini, siswa diminta kembali untuk mengingat kedudukan dua garis yang telah dibahas pada LAS 2, sudut yang terjadi jika dua garis sejajar dipotong oleh dua garis yang telah dibahas pada LAS 3.

Aktivitas 4 ini terdiri dari permasalahan penerapan prinsip hubungan antar garis. Untuk permasalahan pertama siswa menuliskan 3 contoh prinsip penerapan garis sejajar, sedangkan untuk permasalahan kedua siswa menuliskan 3 contoh prinsip penerapan garis berpotongan. Kemudian siswa diminta untuk menuliskan 3 contoh prinsip garis berhimpit. Berikut jawaban siswa dalam menuliskan penerapan prinsip hubungan antar garis, seperti yang terlihat pada gambar 8 berikut:

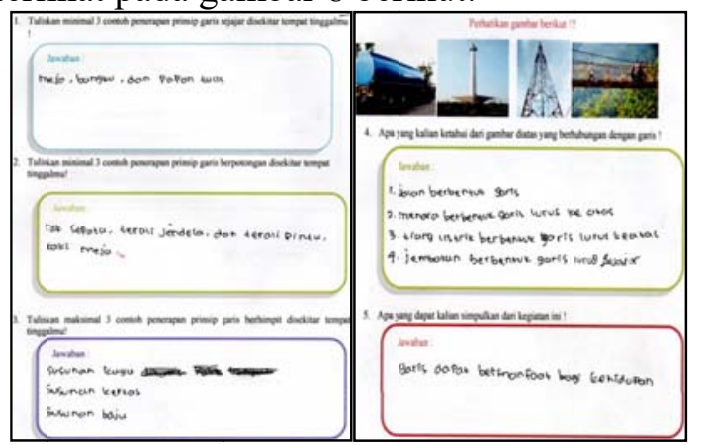

Gambar 8. Penerapan Prinsip Hubungan antar Garis

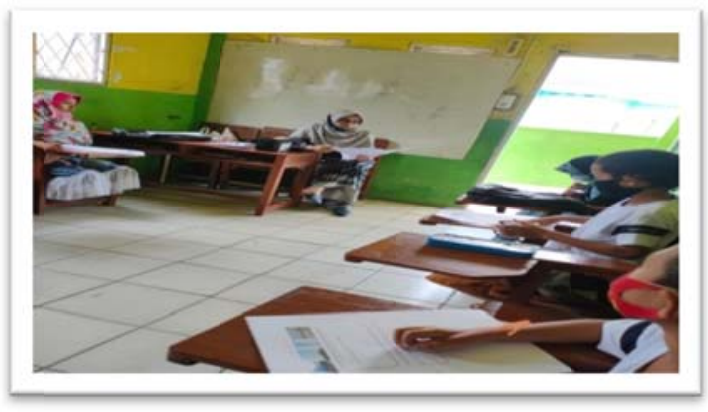

Gambar 9. Kegiatan Siswa pada Aktivitas 4

Kemudian salah satu kelompok tampil di depan kelas untuk mempresentasikan hasil diskusi mereka. Kelompok yang tampil menjelaskan hasil diskusi mereka tentang penerapan prinsip hubungan antar garis dalam kehidupan sehari-hari.

\section{Pembahasan}

Hasil dari design research bukan merancang pekerjaan tetapi membawa prinsip-prinsip dengan menjelaskan 


\section{$\pi$ (Phi)}

bagaimana dan mengapa suatu pekerjaan tersebut dirancang (Wijaya, 2008). Berdasarkan temuan dalam tahap pilot experiment, beberapa aktivitas direvisi untuk mendapatkan hasil yang optimal. Hal seperti ini dilakukan guna mendapatkan data yang akurat sesuai dengan tujuan penelitian. Tidak dilakukan perubahan yang berarti untuk pre-test maupun post-test. Revisi yang dilakukan antara lain pada aktivitas 3 dan aktivitas 4 .

Untuk aktivitas 3, perubahan terdapat pada pemberian soal diakhir kegiatan. Pada saat pilot experiment diberikan satu buah soal diakhir kegiatan dalam menentukan sudut yang terjadi jika dua garis sejajar dipotong oleh sebuah garis. Pada aktivitas 3 hanya sampai menentukan sudut saja. Pada aktivitas keempat terdapat aktivitas mengerjakan soal-soal secara berkelompok. Terdapat 5 soal yang berhubungan dengan aktivitas-aktivitas siswa sebelumnya. Namun pada aktivitas 4 ini guru menjelaskan maksud soal yang ada pada LAS 4, karena siswa kebingungan pada saat menjawab soal LAS 4. Untuk soal post-test dibuat tetap sama pada waktu pilot experiment, yaitu soal yang sejenis dengan soal pre-test tetapi tingkat kesukarannya lebih tinggi.

Dari hasil design research yang telah dilakukan, diperoleh lintasan belajar materi hubungan antar garis menggunakan garis lurus dengan pendekatan PMRI dilakukan di kelas IV SD. Selain itu, diperoleh strategistrategi pemikiran siswa dalam menyelesaikan materi hubungan antar garis. Strategi tersebut merupakan dampak dari penerapan HLT yang telah didesain dan diujicobakan pada tahap pilot experiment kemudian direvisi sehingga dapat diterapkan pada teaching experiment yang akan menghasilkan LIT. Pembelajaran yang dilaksanakan menggunakan garis lurus sebagai starting point untuk mengawali materi hubungan antar garis. Kegiatankegiatan yang ada pada saat mendeskripsikan garis membuat pola pikir siswa lebih luas dalam menjangkau materi

tersebut. Untuk mendukung proses pembelajaran tersebut, maka pendekatan PMRI berperan sangat besar dalam proses pembelajaran yang berlangsung lebih aktif dan efisien.

\section{SIMPULAN}

Dari hasil pengamatan selama proses penelitian berlangsung pada tahap pilot experiment, semua aktivitas dapat diselesaikan dengan baik oleh siswa dan guru. Hal ini menunjukkan lintasan belajar yang dilaksanakan membuat siswa lebih aktif dalam belajar dan memiliki berbagai strategi dalam menemukan pemahaman mengenai materi hubungan antar garis. Hal tersebut terlihat pada keempat aktivitas pembelajaran yang telah dilalui siswa. Siswa mampu bekerjasama menyelesaikan tahap demi tahap pembelajaran. Dengan kemampuan siswa menyelesaikan setiap kegiatan yang diberikan, menunjukkan pemahaman siswa telah memahami konsepkonsep pada materi hubungan antar garis.

\section{DAFTAR PUSTAKA}

Depdiknas. (2006). Kurikulum Tingkat Satuan Pendidikan. Jakarta : Depdiknas.

Gravemeijer, K. (2004). Local Instructional Theories as Means of Support for Teacher in Reform Mathematics Education. Mathematical Thinking and Learning, 6(2), $105-128$.

Gravemeijer, K., \& Cobb, P. (2006). Design Research From a Learning Design Perspective. Educational Design Research, 17 -55.

Hadi, Sutarto. (2017). Pendidikan Matematika Realistik. PT Raja Grafindo Persada.

Jamaris, M. (2013). Orientasi Baru dalam Psikologi Pendidikan. Bogor : Ghalia Indonesia.

Sembiring, R. K. (2010). Pendidikan matematika realistik Indonesia (PMRI): perkembangan dan 
$\pi$ (Phi)

tantangannya. Indonesian

Mathematical Society Journal on Mathematics Education (IndoMSJME). 1(1), 11-16.

Tim MKPBM. (2001). Strategi Pembelajaran Matematika Kontemporer. Bandung : JICA Universitas Pendidikan Indonesia.

Wijaya, A. (2008). Design Research in Mathematics Education: Indonesian Traditional Games as Means to Support Second Graders' Learning Measurement. Thesis Utrecht University. The Netherland: Utrecht University.

----------. (2012). Pendidikan Matematika Realistik : Suatu Alternatif Pendekatan
Jurnal Pendidikan Matematika Volume 5 Nomor 1 Tahun 2021

Z

Zulkardi \& Ilma. (2010). Pengembangan Blog Support untuk Membantu Siswa dan Guru Matematika Indonesia Belajar Pendidikan Matematika Realistik Indonesia (PMRI). Jurnal Inovasi Perekayasa Pendidikan (JIPP), Vol. 2, No. 1, hlm. 1 - 24. 